Robotic Control 
Macmillan New Electronics Series

Series Editor: Paul A. Lynn

R. F. W. Coates, Underwater Acoustic Systems

Paul A. Lynn, Radar Systems

A. F. Murray and H. M. Reekie, Integrated Circuit Design

Dennis N. Pim, Television and Teletext

Martin S. Smith, Introduction to Antennas

P. M. Taylor, Robotic Control

\section{Series Standing Order}

If you would like to receive future titles in this series as they are published, you can make use of our standing order facility. To place a standing order please contact your bookseller or, in case of difficulty, write to us at the address below with your name and address and the name of the series. Please state with which title you wish to begin your standing order. (If you live outside the United Kingdom we may not have the rights for your area, in which case we will forward your order to the publisher concerned.)

Customer Services Department, Macmillan Distribution Ltd Houndmills, Basingstoke, Hampshire, RG21 2XS, England 


\title{
Robotic Control
}

\author{
P. M. Taylor
}

Department of Electronic Engineering

University of Hull

Macmillan New Electronics

Introductions to Advanced Topics

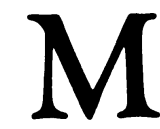

MACMILLAN

EDUCATION 
(C) P. M. Taylor 1990

All rights reserved. No reproduction, copy or transmission of this publication may be made without written permission.

No paragraph of this publication may be reproduced, copied or transmitted save with written permission or in accordance with the provisions of the Copyright Act 1956 (as amended), or under the terms of any licence permitting limited copying issued by the Copyright Licensing Agency, 33-4 Alfred Place, London WC1E 7DP.

Any person who does any unauthorised act in relation to this publication may be liable to criminal prosecution and civil claims for damages.

First published 1990

Published by

MACMILLAN EDUCATION LTD

Houndmills, Basingstoke, Hampshire RG21 2XS

and London

Companies and representatives

throughout the world

British Library Cataloguing in Publication Data

Taylor, P. M.

Robotic control.

1. Robots

I. Title

$629.8^{\prime} 92$

ISBN 978-0-333-43822-0

DOI 10.1007/978-1-349-20510-3

ISBN 978-1-349-20510-3 (eBook) 


\section{Contents}

Series Editor's Foreword vii

Preface viii

Acknowledgements $\quad$ x

1 Introduction 1

1.1 Historical development 1

1.2 Robot definition 4

1.3 Robotics versus hard automation and manual operation 4

$\begin{array}{lll}1.4 & \text { Application requirements } & 6\end{array}$

1.5 Functional elements of robotic control 8

2 Kinematics and Dynamics $\quad 12$

2.1 Degrees of freedom $\quad 12$

$\begin{array}{ll}2.2 \text { Mobility } & 15\end{array}$

$\begin{array}{lll}2.3 & \text { Robot structures } & 17\end{array}$

2.4 End effectors 24

$\begin{array}{ll}2.5 & \text { Kinematic analysis } \\ 2.6 & 26\end{array}$

$\begin{array}{lll}2.6 & \text { Dynamics } & 33\end{array}$

3 Sensors and Actuators $\quad 35$

$\begin{array}{lll}3.1 & \text { Hydraulic actuators } & 35\end{array}$

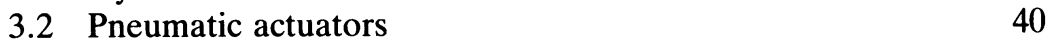

3.3 Direct Current (DC) motors $\quad 40$

3.4 Stepping motors $\quad 44$

3.5 Alternating Current (AC) motors 46

3.6 Evaluation of types of actuator 46

3.7 Transmission systems $\quad 47$

3.8 Position sensors $\quad 52$

3.9 Velocity sensors $\quad 56$

3.10 Accelerometers $\quad 56$

4 Dynamic Control $\quad \mathbf{5 7}$

4.1 Review of linear feedback control theory and techniques 57

4.2 Point-to-point control 65

$\begin{array}{lll}4.3 & \text { Continuous path control } & 67\end{array}$ 
5 Task Control $\quad 69$

5.1 Teaching by guiding (teaching by showing) 69

5.2 Offline programming (manipulator level) 71

6 External Sensors $\quad 76$

$\begin{array}{lll}6.1 & \text { Vision sensors } & 77\end{array}$

6.2 Touch and tactile sensors $\quad 89$

$\begin{array}{lll}6.3 \text { Force sensors } & 92\end{array}$

$\begin{array}{ll}6.4 \text { Other sensors } & 92\end{array}$

$\begin{array}{lll}6.5 & \text { Sensory data processing } & 94\end{array}$

$\begin{array}{lll}\text { 6.6 Sensory task control } & 97\end{array}$

7 Workcell Control $\quad 100$

$\begin{array}{ll}7.1 \text { Workcell mechanisms } & 100\end{array}$

$\begin{array}{ll}7.2 \text { Fixtures } & 106\end{array}$

$\begin{array}{lll}7.3 \text { Communications } & 107\end{array}$

$\begin{array}{ll}7.4 \text { Collision avoidance } & 109\end{array}$

7.5 Illustrative example: handling limp materials 110

8 Future Trends $\quad 118$

$\begin{array}{ll}8.1 \text { Robot arm design } & 118\end{array}$

$\begin{array}{ll}8.2 \text { Actuators } & 119\end{array}$

$\begin{array}{ll}\text { 8.3 Sensors and sensory data processing } & 119\end{array}$

$\begin{array}{ll}8.4 \text { Dynamic control } & 121\end{array}$

8.5 Workcell integration and sensory task control 122

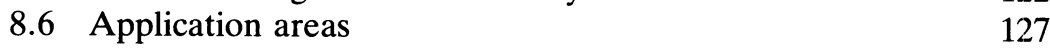

Appendix A: Relationships between Co-ordinate Frames 128

Appendix B: Joint Transformations and their Application to an Elbow Manipulator

Appendix C: Lagrangian Analysis of a Two-link Mechamism 137

$\begin{array}{ll}\text { References } & 139\end{array}$

$\begin{array}{ll}\text { Index } & 147\end{array}$ 


\section{Series Editor's Foreword}

The rapid development of electronics and its engineering applications ensures that new topics are always competing for a place in university and polytechnic courses. But it is often difficult for lecturers to find suitable books for recommendation to students, particularly when a topic is covered by a short lecture module, or as an 'option'.

Macmillan New Electronics offers introductions to advanced topics. The level is generally that of second and subsequent years of undergraduate courses in electronic and electrical engineering, computer science and physics. Some of the authors will paint with a broad brush; others will concentrate on a narrower topic, and cover it in greater detail. But in all cases the titles in the Series will provide a sound basis for further reading of the specialist literature, and an up-to-date appreciation of practical applications and likely trends.

The level, scope and approach of the Series should also appeal to practising engineers and scientists encountering an area of electronics for the first time, or needing a rapid and authoritative update. 


\section{Preface}

Robots have already become standard tools for use in industrial automation systems, mainly where a variety of simple repetitive tasks is carried out. Their key feature, programmability, also allows their operation to be modified according to sensory information about their environment. Their surroundings may now be less well-defined, opening up new application areas and reducing the need for specially made jigs and fixtures. However, there is a long way to go before they can do useful tasks in completely unconstrained environments and before they have intelligence, instead of operating on explicit pre-programmed instructions. Once this has been achieved, the potential of robots will become enormous.

An initial study of robots would comprise an investigation into their mechanical construction, a survey of the types of sensors and actuators which might be used, and how control might be achieved so that the robot can perform the desired movements with the required speed and accuracy.

But practical robotics is much more than this. The robot must interface with its environment, in which there could be objects to be handled, feeding devices, other robots and people. A robot will usually be part of a larger system which can be programmed to perform a multitude of tasks. All of these items are considered here as being part of Robotic Control. The aim of this book is to present the concepts and technologies used in state-of-the-art robots, with an emphasis on fixed-base robots for industrial applications.

The early chapters describe the structure of a robot and its hardware components, followed by a study of how good dynamic control can be achieved. The programming aspects are considered in chapter 5 .

The second part of the book develops the theme of adding external sensors and other equipment to the simple robot, making possible more advanced applications. Chapter 6 starts with an overview of typical external sensors and sensory data processing, and then looks at how this information may be used to enhance the capability of a robot. Workcell mechanisms such as feeders are described in chapter 7 which culminates in an illustrative example of the design of a sensory robotic workcell. Finally, chapter 8 attempts some crystal-ball gazing at future trends, based on reports of work being carried out at research institutes around the world. 
The book is intended as a text for undergraduate courses or as an introduction for graduates new in the area. A basic working knowledge of computers and programming is assumed throughout, and of Laplace transforms in parts of chapters 3 and 4 . 


\section{Acknowledgements}

The author wishes to thank his parents for their early encouragement to pursue a career in engineering. He also wishes to acknowledge the continual support of Gaynor, his wife and colleague. Professor Alan Pugh at Hull University must also be mentioned for his help at the start of the author's research career in robotics.

All photographs are courtesy of the University of Hull unless noted below.

Figures 2.9, 2.10 and 2.13b courtesy GEC-Marconi Research Laboratories and Alvey 'Design to Product' project.

Figure 6.14 courtesy of the Department of Computer Science, University College of Wales, Aberystwyth.

Figure 7.7 courtesy of SATRA Footwear Technology Centre. 